Historic, Archive Document

Do not assume content reflects current scientific knowledge, policies, or practices. 

as $A 48$

Department

of Agriculture

Forest Service

Intermountain

Research Station

General Technical

Report INT-300

August 1993

USS
Reuw Fish Habitat Conditions: Using the Northern/Intermountain Regions' Inventory Procedures for Detecting Differences on Two Differently Managed Watersheds

C. Kerry Overton

Michael A. Radko

Rodger L. Nelson

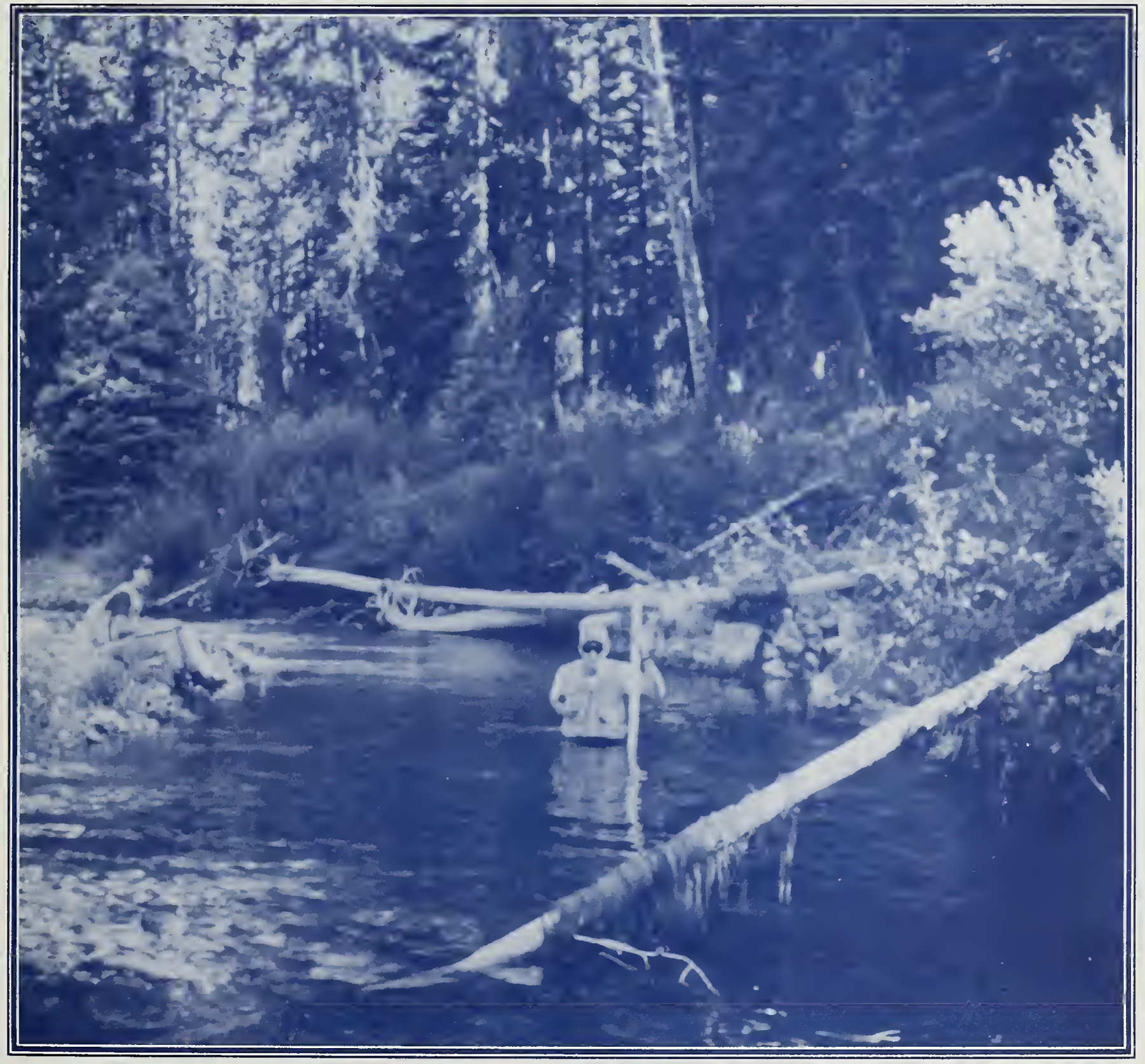




\section{THE AUTHORS}

C. KERRY OVERTON is technology transfer specialist with the Intermountain Research Station's Enhancing Fish Habitats research work unit in Boise, ID. He received B.S. degrees in conservation and biology and an M.S. degree in zoology (aquatic ecology) from Idaho State University. He joined the Forest Service in 1978 and has worked as a fishery biologist at the District, Forest, and Regional levels in the Pacific Southwest Region, California. He joined the intermountain Research Station in November 1990 working on the development, evaluation, and transfer of technical tools to assist National Forest fishery biologists.

MICHAEL A. RADKO is a fisheries biologist with the research work unit in Boise, ID. He received his B.S. degree in zoology from the University of Nevada in 1988. He began work with the Forest Service in 1990 and currently is involved with aquatic habitat inventories and fish habitat relationships.

RODGER L. NELSON is biological technician (fisheries) with the research work unit in Boise, ID. He holds a B.S. degree in biological sciences from the University of California, Irvine, and has pursued graduate study in ecology and business. He joined the Forest Service in 1978 and has been at the Forestry Sciences Laboratory in Boise the entire time. He has participated in Station and interagency cooperative research efforts and has coauthored several Station and journal publications. At present, he is largely responsible for watershed-scale fish habitat inventory database development and management, as well as implementation of the Geographic Information System for his work unit.

\section{RESEARCH SUMMARY}

The R1/R4 [Northern Region/Intermountain Region, Forest Service, U.S. Department of Agriculture] Fish Habitat Inventory Procedures were tested in the summer of 1991 on two mountain watersheds in the Payette National Forest in west-central Idaho: Rapid
River (mostly undisturbed) and Boulder Creek (intensively managed for timber production and harvest). The objectives were (1) to determine whether the inventory parameters would permit detection of differences between the two differently managed watersheds and (2) to provide guidelines for determining sample sizes required to detect these differences.

The two streams were stratified on the basis of drainage area and Rosgen channel types (Rosgen 1985), and then, with a hierarchical habitat typing scheme, they were classified into fluvial geomorphic units. The estimated habitat variables described channel morphology, substrate, large woody debris, and bank conditions. A subset was measured to provide a basis for correcting estimated values.

Depending on the level of analysis (basin, channel type, channel type with equal drainage area), several habitat variables-including mean width, mean and mean maximum depth, frequency and depth of pocket pools, width to depth ratio, pool tail depth, single pieces of large woody debris, and surface fines-were significantly different $(p<0.05)$ for "B" channel types between the two watersheds. These differences are likely related to differences in management of the two watersheds.

For most habitat variables, 30 habitat units proved adequte for evaluating differences between streams. This corresponded to 10 percent of the sampled units, which would be a considerable decrease in sampling effort. Other studies may require a different sampling ratio.

\section{ACKNOWLEDGMENTS}

This study was funded by the Forest Service's Intermountain Region Fish and Wildlife staff, Payette National Forest, and Intermountain Research Station. Dave Burns, Payette National Forest biologist, contributed substantially to the development of this study. Data collection, entry, proofing, and summaries were compiled by field technicians from the University of Idaho and Intermountain Station. 


\title{
Fish Habitat Conditions: Using the Northern/Intermountain Regions' Inventory Procedures for Detecting Differences on Two Differently Managed Watersheds
}

\author{
C. Kerry Overton \\ Michael A. Radko \\ Rodger L. Nelson
}

\section{INTRODUCTION}

Fishery biologists working for the Forest Service, U.S. Department of Agriculture, are required to assess the effects of forest and rangeland management practices on fish habitat on land administered by the agency. To do this, biologists need cost-effective inventory and monitoring tools for detecting differences in habitat conditions between streams. Once such tools are available, land managers still need methods to assess what part of observed differences reflect natural variation among streams and what can be attributed to human-induced disturbances. This is the object of continuing work at the Intermountain Station's Boise Forestry Sciences Laboratory.

The Forest Service's R1/R4 [Northern Region/Intermountain Region] Fish Habitat Inventory Procedures contain a standard set of variables describing stream channels. These variables are assumed to have ecological significance to fish and were identified through formal meetings with Northern Region, Intermountain Region, and Intermountain Research Station fishery biologists. We used the procedures on two differently managed streams in the Payette National Forest, ID, with two objectives: (1) to determine if the sampled habitat variables provide a basis for detecting differences between the two streams and (2) to provide guidelines for assessing the sample size requirements to detect observed differences.

\section{STUDY AREA}

Boulder Creek and Rapid River are adjacent and principal tributaries of the Little Salmon River watershed in west-central Idaho, about $50 \mathrm{~km}$ northwest of McCall (fig. 1). Watersheds are similar in elevation, climatic conditions, parent geology, and upland and streamside vegetation. Rapid River has only been incidentally affected by forest development, whereas Boulder Creek watershed has been intensively managed for timber harvest. Although portions of Rapid River occur in the Nez Perce National Forest, our survey was restricted to reaches in the New Meadows Ranger District of the Payette National Forest. Boulder Creek lies wholly within the New Meadows Ranger District.

Boulder Creek (table 1) is the smaller of the two study watersheds, comprising approximately 10,188 ha (USDA FS 1992), and joins the Little Salmon River at river kilometer 16 . Forest overstory in the Boulder Creek watershed includes Englemann spruce (Picea engelmannii), grand fir (Abies grandis), Douglas-fir (Pseudotsuga menziesii), and ponderosa pine (Pinus ponderosa). Riparian vegetation also includes alder (Alnus incana), red-osier dogwood

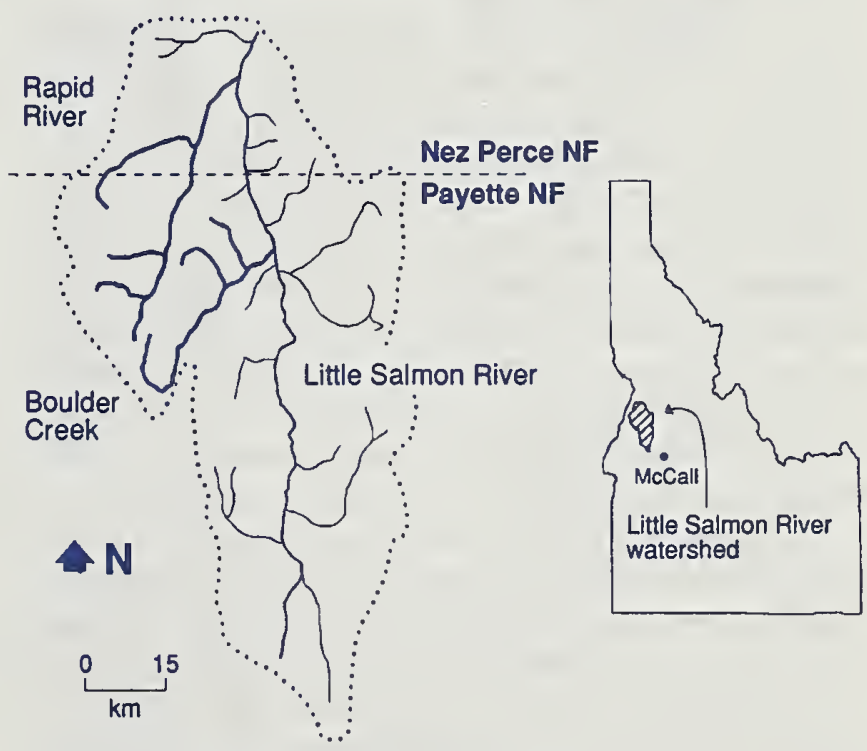

Figure 1-Location of Rapid River and Boulder Creek within the Little Salmon River watershed. 
Table 1-Watershed descriptors for Rapid River and Boulder Creek

\begin{tabular}{|c|c|c|}
\hline Descriptor & Rapid River & Boulder Creek \\
\hline Drainage area (ha) & 30,925 & 10,188 \\
\hline Study area (ha) & 16,751 & 10,188 \\
\hline Gross geology & $\begin{array}{l}\text { Seven Devils } \\
\text { Meta-volcanics }\end{array}$ & $\begin{array}{l}\text { Seven Devils } \\
\text { Meta-volcanics }\end{array}$ \\
\hline $\begin{array}{l}\text { Precipitation }(\mathrm{cm}) \\
\text { mean } \\
\text { range }\end{array}$ & $\begin{array}{l}85.10 \\
48.30-121.90\end{array}$ & $\begin{array}{l}88.90 \\
-\end{array}$ \\
\hline Stream order range & $3 d-5$ th & $2 d-4$ th \\
\hline $\begin{array}{l}\text { Elevation }(\mathrm{m}) \\
\text { mean } \\
\text { range }\end{array}$ & $\begin{array}{l}1,344.00 \\
975.40-1,724.50\end{array}$ & $\begin{array}{l}1,344.40 \\
926.60-1,645.30\end{array}$ \\
\hline Riparian vegetation & $\begin{array}{l}\text { Alder, dogwood, willows, } \\
\text { ribes, huckleberry, spruce, } \\
\text { Douglas-fir, ponderosa pine }\end{array}$ & $\begin{array}{l}\text { Alder, dogwood, willows, } \\
\text { ribes, huckleberry, spruce, } \\
\text { Douglas-fir, ponderosa pine }\end{array}$ \\
\hline Timber types & Spruce/Douglas-fir, pine & Spruce/Douglas-fir, pine \\
\hline Land management & $\begin{array}{l}\text { Wild and scenic river } \\
\text { Proposed wilderness } \\
\text { Dispersed recreation }\end{array}$ & $\begin{array}{l}\text { Irrigation, grazing } \\
\text { Roaded acres } 72.10 \\
\text { Logged acres } 1,229\end{array}$ \\
\hline Mean width $(m)$ & 7.93 & 7.05 \\
\hline Survey length (km) & 11.10 & 16.40 \\
\hline $\begin{array}{l}\text { Stream } \\
\text { temperature }\left({ }^{\circ} \mathrm{C}\right)\end{array}$ & $\begin{array}{l}4.20-13.20 \\
(6 / 01-8 / 31 / 70) \\
7.50-12.20 \\
(7 / 30 / 91-8 / 07 / 91)\end{array}$ & $\begin{array}{l}6.00-17.00 \\
(7 / 17 / 91-7 / 24 / 91)\end{array}$ \\
\hline
\end{tabular}

(Cornus stolonifera), willow (Salix spp.), and gooseberry (Ribes spp.). The watershed annually receives an average $88.9 \mathrm{~cm}$ of precipitation, mostly as snow from October through May.

The Boulder Creek watershed has been managed for timber production since 1961. Other significant activities include road construction, livestock grazing, water diversion, recreation, and fuelwood gathering (USDA FS 1991). In 1989 and 1990, windthrown Englemann spruce in the riparian zone were removed, and large diameter spruce within the riparian zone have been selectively removed in some portions of the watershed. Yantis Ditch, in the uppermost reach, diverts an estimated 80 to 90 percent of the main flow of Boulder Creek to the adjacent Weiser River drainage for summer irrigation.

The Rapid River watershed encompasses 30,925 ha (USDA FS n.d.) with portions of the watershed in the Nez Perce and Payette National Forests. Rapid River enters the Little Salmon River at river kilometer 6. Forest overstory includes ponderosa pine, grand fir, Douglas-fir, and Englemann spruce. Riparian vegetation also includes alder, dogwood, willow, gooseberry, and huckleberry (Vaccinium spp.). The watershed receives an average $85 \mathrm{~cm}$ of precipitation annually, mostly as snow from October to April. Our studies in Rapid River were conducted solely in the Payette National Forest, including 16,751 ha of the upper basin. Rapid River is classified a Wild and Scenic River (USDA FS n.d.). The only major road in the drainage parallels the lower $3 \mathrm{~km}$ of the stream and is not within the surveyed reach. There are no major land-disturbing activities within Rapid River above the Payette/Nez Perce National Forest boundary (fig. 1). The basin is used for recreation and has a trail system. Livestock grazing is permitted in part of the basin, and some suppression of natural fire has occurred.

\section{METHODS}

We surveyed $16.4 \mathrm{~km}$ of the Boulder Creek drainage and $11.1 \mathrm{~km}$ of the Rapid River drainage above the Payette National Forest boundary. Boulder Creek and Rapid River were stratified using two reach break criteria: (1) a named tributary (identifiable on 1:24,000 scale maps) entering the stream and contributing more than 10 percent to the main 

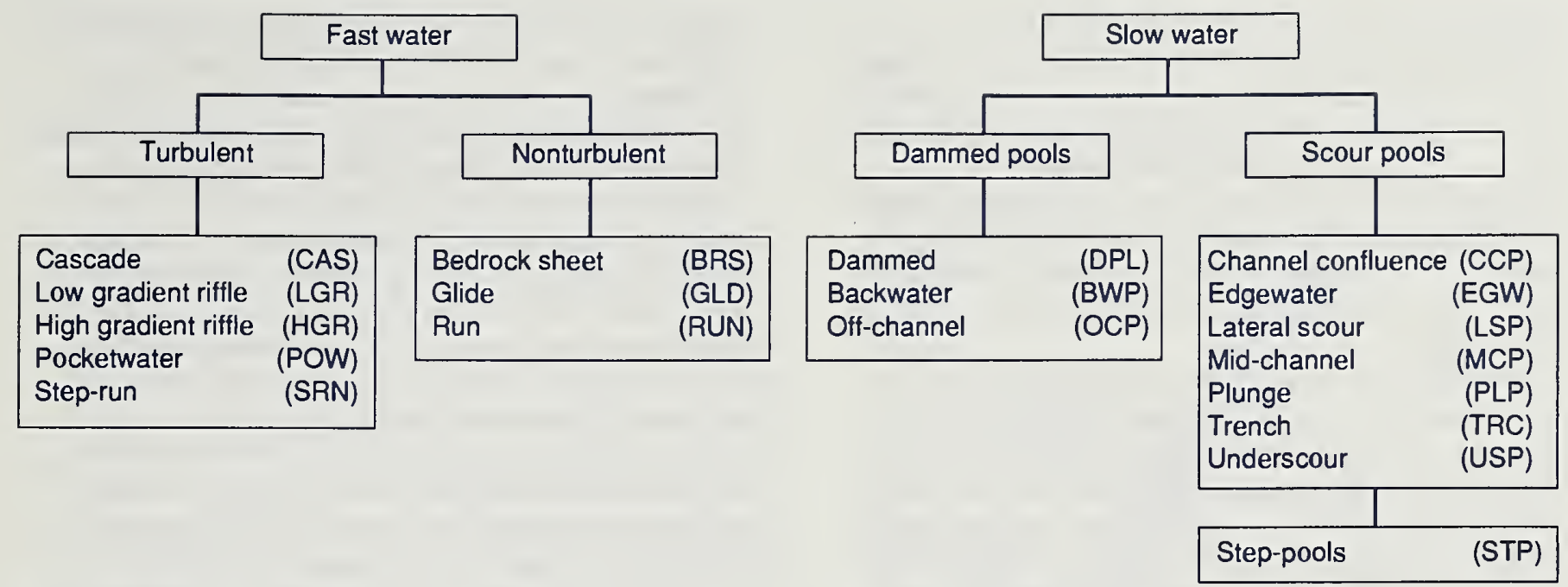

Figure 2-Hierarchical habitat typing scheme and codes used to stratify Rosgen (1985) channel types into like habitat types within Boulder Creek and Rapid River.

channel stream flow and (2) observed change in gross-scale Rosgen channel type ("A", "B", "C") as determined by gradient and channel confinement (Rosgen 1985).

We further stratified stream reaches into discrete, objectively identifiable geomorphic units called habitat types. Habitat types were first described by Bisson and others (1982) and have been modified by others to characterize habitat for different species across a wide range of streams (such as Bozek and Rahel 1991; Hankin and Reeves 1988; Kozel 1987; Lobb and Orth 1991; McCain and others 1990; Modde and others 1991). We used a hierarchical scheme to agglomerate habitat types within slow and fast water categories (fig. 2). The boundaries of a habitat type were identified as breaks in slope along the stream's thalweg.

\section{Habitat Type Variables}

Attributes of habitat types (table 2) were used to describe channel characteristics. We made ocular estimates of attribute values for each habitat type and measured values for every fifth like-habitat type to develop correction factors (Hankin and Reeves 1988) for the ocular estimates.

Mean width, mean depth, and thalweg length were estimated. Width estimates were verified by averaging subsample measurements collected at distances of one-fourth, one-half, and three-fourths of the thalweg length. We estimated average depth for a given habitat type by prodding a calibrated survey rod at several arbitrarily determined locations. We verified mean depth by measurements along transects located at distances one-fourth, onehalf, and three-fourths the thalweg length. In each transect, three depths were taken at one-fourth, one-half, and three-fourths the wetted width. To calculate average measured depth, the nine measurements were summed and divided by 12 (at each transect a measure of zero is included to account for a theoretical depth of zero at the banks). Maximum habitat depth was located and measured for every habitat type using a survey rod. We calculated a width-to-depth ratio by dividing the wetted average

Table 2-List of field collected and calculated variables for each habitat type

\begin{tabular}{lc}
\hline $\begin{array}{c}\text { Field-measured } \\
\text { variables }\end{array}$ & $\begin{array}{c}\text { Calculated } \\
\text { variables }\end{array}$ \\
\hline $\begin{array}{l}\text { Habitat type dimensions } \\
\text { Thalweg length }\end{array}$ & $\begin{array}{c}\text { Habitat type dimensions } \\
\text { Width }\end{array}$ \\
Area \\
Vopth & Pool dimensions \\
Maximum depth & Residue maximum depth \\
Pool tail depth & Residual pool volume \\
Pocket pool & Width/depth ratio \\
Frequency & Large woody debris \\
Mean depth & Size classes \\
Surface fines & Volume \\
Pool tails & Frequency (No./100 m) \\
Low gradient riffles & \\
Substrate composition & \\
Large woody debris & \\
Numbers & \\
Dimensions & \\
Bank condition & \\
Bank stability & \\
\hline
\end{tabular}


width by average depth for each habitat type. To compensate for unequal habitat unit sizes, average width was weighted by reach area and average depth by reach volume. Weighted widths and depths were used in width to depth ratio calculations.

Pocket pools (small pools less $1 \mathrm{~m}^{2}$ ) formed behind channel obstructions (typically boulders and logs) were counted, and an average maximum pocket pool depth was calculated and recorded for each habitat type.

Substrate composition was estimated for the entire submerged area of a habitat type, except in pools where the estimate was made only in the tails (pool tails are the transitional portion of stream between a slow and fast water habitat type and are critical sites used by spawning fish). Substrate was classified by the percentage of particles that were fines (less than $0.2 \mathrm{~cm}$ ), gravels $(0.2$ to $7.5 \mathrm{~cm}$ ), rubble ( 7.5 to $15 \mathrm{~cm}$ ), cobble ( 15 to $30 \mathrm{~cm}$ ), boulder (more than $30 \mathrm{~cm}$ ), and bedrock. A pebble count (Wolman 1954) verified the ocular estimates of substrate at every fifth habitat type.

We measured and recorded maximum depth in tails of pools. Residual pool maximum depth was calculated by subtracting the pool maximum depth from the pool tail maximum depth. Residual pool volume was calculated by multiplying the residual pool maximum depth by the total pool area (Lisle 1989).

We inventoried large woody debris (LWD) in the bankfull channel of all habitat units. Large woody debris is defined as pieces of wood at least $3 \mathrm{~m}$ in length or two-thirds the channel width and $0.1 \mathrm{~m}$ in diameter at one-third the distance from the large end. Each single piece was counted, and the length and diameter were estimated in every habitat type. To develop correction factors for LWD dimensions, we collected at least 10 or more measurements of pieces per day. Aggregates-defined as two or more single pieces acting together-were counted, the number of pieces were estimated, and the length, width, and depth of the aggregate were estimated. Rootwads were counted, and the length and diameter were estimated.

We took water and air temperatures and time of day at reference points throughout the survey. Water and air temperatures were taken each morning, noon, and afternoon.

\section{Statistical Analysis}

We evaluated habitat type variables from four perspectives. On an overall basis, we computed summary statistics for each study area. Because of differences in the characteristics of the watersheds, we also looked at summary statistics for " $\mathrm{B}$ " channels only (Rapid River had no " $\mathrm{C}$ " channel within the study area). Because the Rapid River watershed is larger than that of Boulder Creek, we used a planimeter to select only the Rapid River " $B$ " channel reaches that drained a catchment area similar in size to that of the Boulder Creek study area. Using the Payette National Forest's Subwatershed Inventory Map (1:126,720 scale), we determined that this included all of Rapid River above Paradise Creek (approximately 15 percent larger than the total Boulder Creek watershed). However, the Boulder Creek summertime flow is reduced because of the Yantis Ditch diversion. The diversion is hand constructed each summer and should not have any effect on channel shaping flows. Finally, we computed summary statistics for pool habitats within the "B" channel similar drainage areas only.

We calculated means and standard deviations for each habitat type variable and used a $t$-test to look for statistically detectable differences in the means of the variables between the two streams. We did not assume equality of variances and tested whether comparisons of means should be based on equal or unequal variances. For tests in which actual probabilities are not shown, such as equality of variances, we used an alpha level of 0.05 .

Habitat type variable means and standard deviations are calculated from sampling of all habitat types within the inventoried reaches of the stream. This is labor intensive and costly. We wanted to determine if the sampling effort could be reduced by sampling only a portion of the habitat types.

We reduced the full data set by eliminating habitat units to simulate sampling at frequencies of 67 , $50,33,25,20$, and 10 percent. We looked at the similarity of means and standard devisions and at the ability to detect differences between streams at various frequencies and similar frequencies to see if the reduced samples provided equivalent habitat information for less effort. We also selected variables that appeared to be useful indicators of habitat differences between streams, and plotted required sample size against detectable change for several levels of significance and test power (Parkinson and others 1988). The "power" of a test, calculated as 1-beta, indicates its ability to detect differences between two means that are, in fact, different. To produce these graphs, we used the following equation:

$$
N=100^{2} k(S D / \bar{X})^{2} / p^{2}
$$

where $N$ is required sample size, $S D$ is the sample standard deviation, $\bar{X}$ is the sample mean, $p$ is the detectable change expressed as a percentage of the mean, and $k$ is a constant determined by alpha and beta (Parkinson and others 1988). We used the sample statistics from the " $\mathrm{B}$ " channel stratification (unequal drainages) for these computations. Unequal drainages were used because they produced a 
larger sample size and, therefore, a better estimate of the true variance.

We assumed that all variables were distributed normally. For purposes of estimating required sample sizes, minor errors resulting from lack of normality should be unimportant because we are suggesting sampling frequencies as general guidelines and not prescribing precise sampling needs.

\section{RESULTS}

Nine study reaches in Boulder Creek and seven in Rapid River were identified (figs. 3, 4). Boulder Creek was 12.4 percent " $A$ " channel, 79.8 percent " $B$ " channel, and 7.8 percent " $C$ " channel, whereas Rapid River was 26.4 percent " $A$ " channel and 73.6 percent " $B$ " channel.

\section{Habitat Differences}

Overall and "B" Channels-Comparison of mean habitat values between study areas, irrespective of drainage area or channel type, revealed the importance of stratifying by these categories. Several habitat variables were significantly different between the two watersheds at this level when compared directly (table 3 ) or when only " $B$ " channels were compared (table 4). Mean depths (average and maximum) were higher in Rapid River than in Boulder Creek. The frequency and mean depth of pocket

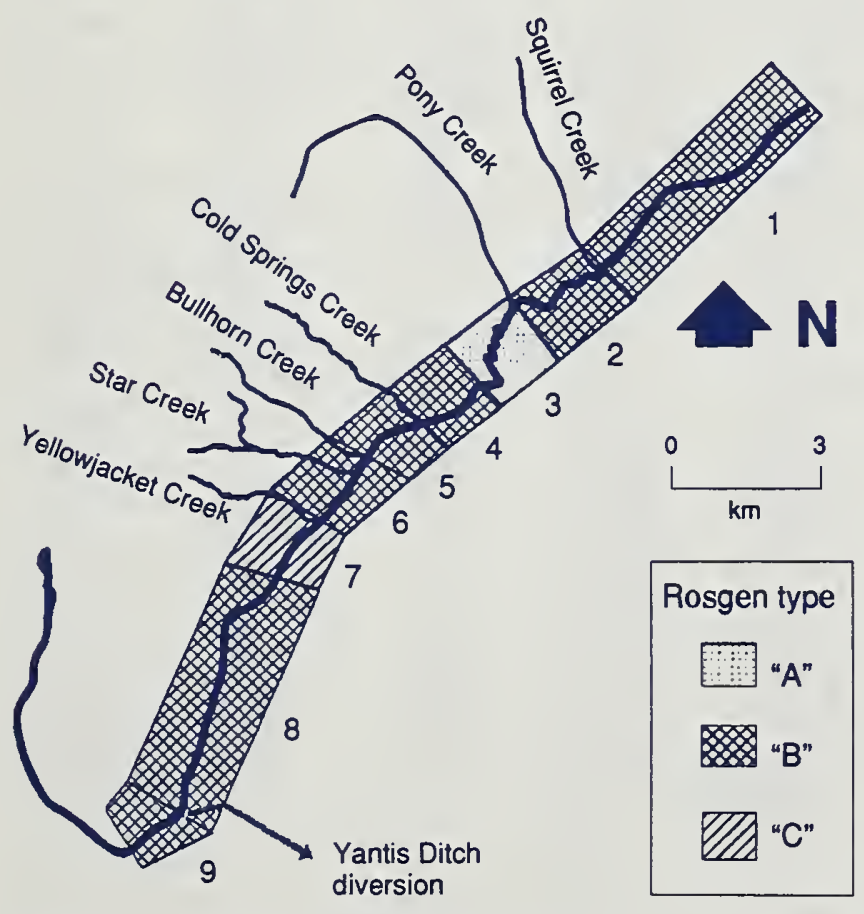

Figure 3-Location of channel types and numbered reach breaks for Boulder Creek.

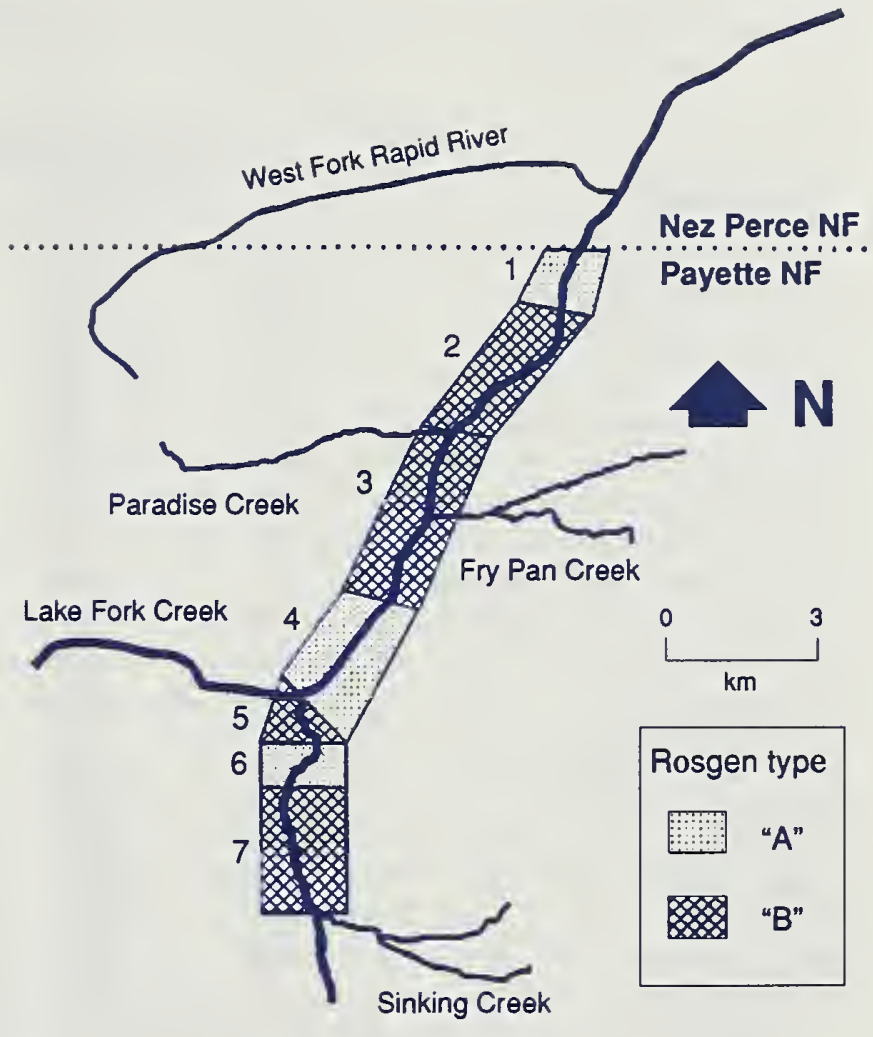

Figure 4-Location of channel types and numbered reach breaks for Rapid River.

pools were greater in Rapid River than in Boulder Creek, and Rapid River exhibited deeper pool tails and greater habitat type water volume, on average, than Boulder Creek. However, mean volume differences were not significant when only " $B$ " channels were compared. At these levels of analysis, surface substrate in Rapid River had a smaller percentage of surface fines, gravel, and rubble and a greater percentage of cobble and boulder than did Boulder Creek. Single pieces and aggregates of large woody debris were nearly twice as abundant in Rapid River as in Boulder Creek. Mean LWD length increased with increasing mean LWD diameter in Rapid River. However, in Boulder Creek mean LWD length began decreasing with increasing mean LWD diameters for pieces greater than $0.6 \mathrm{~m}$ in diameter (fig. 5). Width-to-depth ratios were lower in Rapid River than in Boulder Creek.

Similar Drainage Areas-Comparison of mean habitat values for similar sized drainage areas showed fewer differences between the two watersheds. Habitat type dimensional variables that were significantly different at the overall and " $\mathrm{B}$ " channel levels (width, mean depth, area, and volume) were not significantly different when similar-sized drainage areas were compared (table 5). Maximum 
Table 3-Summary statistics for habitat type variables and analysis of variance comparisons between Boulder Creek and Rapid River

\begin{tabular}{|c|c|c|c|c|c|c|c|}
\hline \multirow[b]{2}{*}{ Variable } & \multicolumn{3}{|c|}{ Boulder Creek } & \multicolumn{3}{|c|}{ Rapid River } & \multirow{2}{*}{$\begin{array}{c}\text { Significance } \\
P=\end{array}$} \\
\hline & $n$ & Mean & SD & $n$ & Mean & SD & \\
\hline Habitat length $(m)$ & 517 & 45.49 & 53.49 & 336 & 47.70 & 43.19 & 0.5259 \\
\hline Habitat width (m) & 517 & 7.05 & 2.34 & 335 & 7.93 & 2.29 & .0001 \\
\hline Habitat area $\left(\mathrm{m}^{2}\right)$ & 517 & 326.35 & 413.35 & 335 & 396.65 & 406.92 & .0149 \\
\hline Habitat mean depth (m) & 517 & .29 & .11 & 333 & .33 & .11 & .0001 \\
\hline Habitat maximum depth $(m)$ & 515 & .64 & .27 & 333 & .81 & .24 & .0001 \\
\hline Habitat volume $\left(\mathrm{m}^{3}\right)$ & 517 & 100.55 & 158.78 & 333 & 129.77 & 148.05 & .0073 \\
\hline Pocket pools (n/100 m) & 517 & 4.67 & 5.69 & 336 & 12.26 & 40.68 & .0001 \\
\hline Pocket pool depth $(\mathrm{m})$ & 281 & .38 & .15 & 280 & .47 & .13 & .0001 \\
\hline Residual maximum depth $(\mathrm{m})$ & 140 & .52 & .19 & 53 & .57 & .30 & .1917 \\
\hline Residual pool volume $\left(\mathrm{m}^{3}\right)$ & 140 & 54.34 & 36.49 & 53 & 56.72 & 50.84 & .7184 \\
\hline Pool tail depth $(m)$ & 160 & .26 & .12 & 102 & .38 & .11 & .0001 \\
\hline Width/depth ratio & 517 & 27.10 & 12.04 & 333 & 26.37 & 11.04 & ${ }^{1} .3729$ \\
\hline Single LWD/100 m & 517 & 3.38 & 5.71 & 336 & 6.81 & 15.52 & .0001 \\
\hline Aggregate LWD/100 m & 517 & 1.12 & 3.06 & 336 & 3.05 & 28.90 & .1336 \\
\hline Rootwad LWD/100 m & 517 & .21 & 1.18 & 336 & .27 & 1.48 & .5394 \\
\hline Percent fines & 510 & 13.61 & 11.00 & 333 & 8.18 & 5.60 & .0001 \\
\hline Percent gravel & 510 & 23.77 & 14.86 & 333 & 18.69 & 7.15 & .0001 \\
\hline Percent rubble & 510 & 24.67 & 9.26 & 333 & 20.87 & 4.69 & .0001 \\
\hline Percent cobble & 510 & 16.46 & 8.46 & 333 & 21.35 & 5.84 & .0001 \\
\hline Percent boulder & 510 & 19.14 & 13.78 & 333 & 29.20 & 8.70 & .0001 \\
\hline
\end{tabular}

${ }^{1} T$-test for equal variances used.

Table 4-Summary statistics of "B" Rosgen channel type habitat type variables and analysis of variance comparisons between Rapid River and Boulder Creek

\begin{tabular}{|c|c|c|c|c|c|c|c|}
\hline \multirow[b]{2}{*}{ Variable } & \multicolumn{3}{|c|}{ Boulder Creek } & \multicolumn{3}{|c|}{ Rapid River } & \multirow{2}{*}{$\begin{array}{c}\text { Significance } \\
P=\end{array}$} \\
\hline & $n$ & Mean & SD & $n$ & Mean & SD & \\
\hline Habitat length (m) & 394 & 47.60 & 57.26 & 252 & 46.61 & 41.99 & 0.8134 \\
\hline Habitat width (m) & 394 & 7.12 & 2.51 & 251 & 7.87 & 2.32 & .0002 \\
\hline Habitat area $\left(m^{2}\right)$ & 394 & 340.73 & 438.77 & 251 & 387.20 & 402.61 & .1763 \\
\hline Habitat mean depth $(m)$ & 394 & .27 & .11 & 250 & .32 & .10 & .0001 \\
\hline Habitat maximum depth $(m)$ & 392 & .59 & .25 & 250 & .80 & .25 & .0001 \\
\hline Habitat volume $\left(\mathrm{m}^{3}\right)$ & 394 & 101.12 & 168.23 & 250 & 121.50 & 136.38 & .1087 \\
\hline Pocket pools ( $n / 100 \mathrm{~m})$ & 394 & 5.01 & 5.86 & 252 & 10.71 & 7.20 & .0001 \\
\hline Pocket pool depth $(\mathrm{m})$ & 228 & .37 & .15 & 213 & .47 & .13 & .0001 \\
\hline Residual maximum depth $(\mathrm{m})$ & 91 & .48 & .18 & 39 & .55 & 29 & .0978 \\
\hline Residual pool volume $\left(\mathrm{m}^{3}\right)$ & 91 & 44.17 & 30.48 & 39 & 57.20 & 55.41 & .0877 \\
\hline Pool tail depth $(m)$ & 104 & .25 & .12 & 78 & .38 & .11 & .0001 \\
\hline Width/depth ratio & 394 & 28.77 & 12.63 & 250 & 26.99 & 11.08 & 1.0606 \\
\hline Single LWD/100 m & 394 & 3.53 & 6.05 & 252 & 5.98 & 8.39 & .0001 \\
\hline Aggregate LWD/100 m & 394 & 1.23 & 3.33 & 252 & 1.13 & 2.54 & .6002 \\
\hline Rootwad LWD/100 m & 394 & .25 & 1.31 & 252 & .17 & .95 & .4248 \\
\hline Percent fines & 389 & 12.23 & 8.83 & 250 & 8.21 & 5.27 & .0001 \\
\hline Percent gravel & 389 & 22.29 & 12.52 & 250 & 18.46 & 6.41 & .0001 \\
\hline Percent rubble & 389 & 25.94 & 8.63 & 250 & 20.95 & 4.70 & .0001 \\
\hline Percent cobble & 389 & 17.81 & 7.84 & 250 & 21.00 & 5.24 & .0001 \\
\hline Percent boulder & 389 & 19.55 & 11.96 & 250 & 29.41 & 8.59 & .0001 \\
\hline
\end{tabular}

${ }^{1} T$-test for equal variances used. 


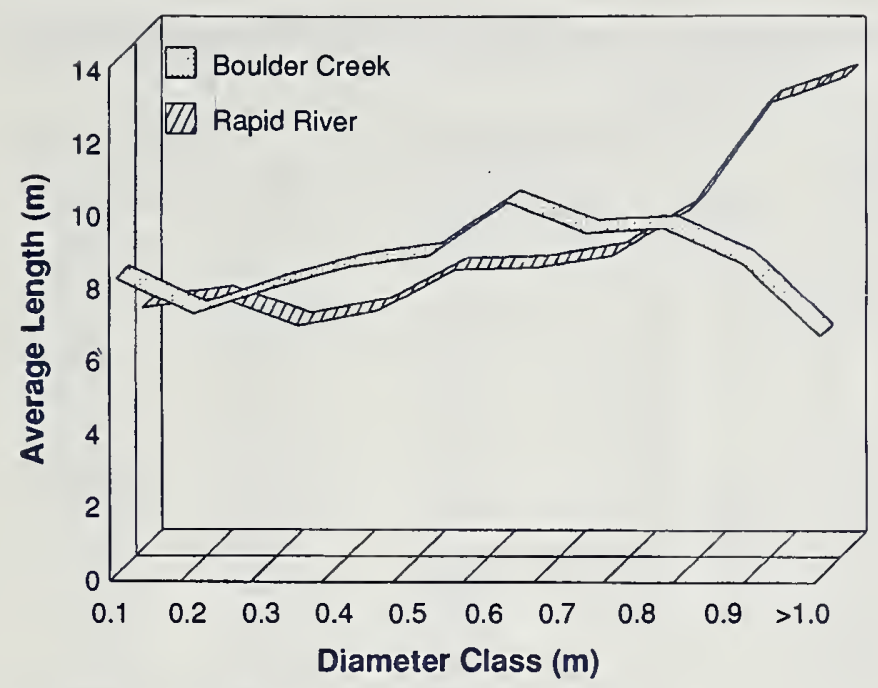

Figure 5-Boulder Creek and Rapid River comparisons of mean length versus mean diameter for single large woody debris.

habitat depth, pocket pool depth and frequency, and single pieces of $\mathrm{LWD} / 100 \mathrm{~m}$ were still significantly higher $(p<0.01)$ in Rapid River. Rapid River substrate composition still had significantly fewer $(p<0.01)$ fine sediments. Frequencies of LWD singles in Rapid River were still nearly double those observed in Boulder Creek. The LWD aggregate frequencies were no longer significantly different between the watersheds.

Pools Only-Comparisons of pool habitat types between study areas with similar drainage areas showed similar differences as detected in the previous comparison using like drainage areas. Pools in Rapid River were greater in length, area, and volume than pools in Boulder Creek (table 6). Pools were deeper and held lower amounts of fine material in Rapid River than in Boulder Creek. Single pieces of LWD in Rapid River pools were twice those observed in Boulder Creek pools. Of the variables associated only with pool habitat types (residual maximum depth and volume, and pool tail depth), pool tail depth alone was significantly greater $(p<0.01)$ in Rapid River. No differences were detected between watersheds for residual pool depth and volume.

Frequencies of shallow ( $<1 \mathrm{~m}$ maximum depth) and deep ( $>1 \mathrm{~m}$ maximum depth) pools were compared between watersheds using three levels of analysis: overall, " $\mathrm{B}$ " channels only, and " $\mathrm{B}$ " channels with similar-sized drainage areas. At all three levels, Rapid River had two- to threefold greater frequency of deep pools than Boulder Creek (table 7).

Mean water temperature in Rapid River was $9.7^{\circ} \mathrm{C}$ with a range of 7.5 to $12.2^{\circ} \mathrm{C}$. In Boulder Creek, temperature ranged from 6.0 to $17.0^{\circ} \mathrm{C}$ with a mean of $11.6^{\circ} \mathrm{C}$. Boulder Creek logged tributaries had a mean high of $12^{\circ} \mathrm{C}$, where Rapid River tributaries had a mean high of $8^{\circ} \mathrm{C}$.

Table 5-Summary statistics of "B" Rosgen channel type habitat type variables and t-test comparisons between Rapid River and Boulder Creek for similar drainage areas

\begin{tabular}{|c|c|c|c|c|c|c|c|}
\hline \multirow[b]{2}{*}{ Variable } & \multicolumn{3}{|c|}{ Boulder Creek } & \multicolumn{3}{|c|}{ Rapid River } & \multirow{2}{*}{$\begin{array}{c}\text { Significance } \\
P=\end{array}$} \\
\hline & $n$ & Mean & SD & $n$ & Mean & SD & \\
\hline Habitat length (m) & 394 & 47.60 & 57.26 & 178 & 43.81 & 37.37 & 0.3458 \\
\hline Habitat width (m) & 394 & 7.12 & 2.51 & 177 & 6.99 & 1.92 & .4273 \\
\hline Habitat area $\left(\mathrm{m}^{2}\right)$ & 394 & 340.73 & 438.77 & 177 & 320.38 & 317.44 & .5318 \\
\hline Habitat mean depth (m) & 394 & .27 & .11 & 177 & .29 & .09 & .2027 \\
\hline Habitat maximum depth (m) & 392 & .59 & .25 & 177 & .72 & .22 & .0001 \\
\hline Habitat volume $\left(\mathrm{m}^{3}\right)$ & 394 & 101.16 & 168.23 & 177 & 87.45 & 83.85 & .1948 \\
\hline Pool volume & 106 & 35.59 & 40.52 & 53 & 63.03 & 62.80 & .0050 \\
\hline Pocket pools $(n / 100 \mathrm{~m})$ & 394 & 5.00 & .06 & 178 & 11.12 & .08 & .0051 \\
\hline Pocket pool depth (m) & 228 & .37 & .15 & 151 & .46 & .13 & .0001 \\
\hline Width/depth ratio & 394 & 28.77 & 12.63 & 177 & 26.81 & 11.66 & ${ }^{1} .0807$ \\
\hline Single LWD/100 m & 394 & 3.53 & 6.05 & 178 & 7.04 & 9.44 & .0001 \\
\hline Aggregate LWD/100 m & 394 & 1.25 & 3.33 & 178 & 1.27 & 2.83 & .9601 \\
\hline Rootwad LWD/100 m & 394 & .25 & 1.31 & 178 & .19 & 1.10 & .6133 \\
\hline Percent fines & 389 & 12.23 & 8.83 & 176 & 9.66 & 5.35 & .0001 \\
\hline Percent gravel & 389 & 22.29 & 12.52 & 176 & 19.02 & 6.83 & .0001 \\
\hline Percent rubble & 389 & 25.93 & 8.63 & 176 & 20.64 & 4.85 & .0001 \\
\hline Percent cobble & 389 & 17.81 & 7.84 & 176 & 21.19 & 5.64 & .0001 \\
\hline Percent boulder & 389 & 19.55 & 11.96 & 176 & 27.23 & 8.60 & .0001 \\
\hline
\end{tabular}

${ }^{1} T$-test for equal variances used. 
Table 6-Summary statistics of "B" Rosgen channel type habitat pool variables and t-test comparisons between Rapid River and Boulder Creek for similar drainage areas

\begin{tabular}{|c|c|c|c|c|c|c|c|}
\hline \multirow[b]{2}{*}{ Variable } & \multicolumn{3}{|c|}{ Boulder Creek } & \multicolumn{3}{|c|}{ Rapid River } & \multirow{2}{*}{$\begin{array}{c}\text { Significance } \\
P=\end{array}$} \\
\hline & $n$ & Mean & SD & $n$ & Mean & SD & \\
\hline Habitat length (m) & 106 & 16.04 & 11.84 & 54 & 26.31 & 24.01 & 0.0042 \\
\hline Habitat width (m) & 106 & 6.61 & 2.21 & 53 & 6.52 & 1.77 & ${ }^{1} .7769$ \\
\hline Habitat area $\left(m^{2}\right)$ & 106 & 106.84 & 101.29 & 53 & 176.31 & 169.87 & .0077 \\
\hline Habitat mean depth (m) & 106 & .32 & .11 & 53 & .36 & .09 & .0357 \\
\hline Habitat maximum depth (m) & 105 & .72 & .25 & 53 & .86 & .25 & ${ }^{1} .0019$ \\
\hline Habitat volume $\left(\mathrm{m}^{3}\right)$ & 106 & 35.59 & 40.52 & 53 & 63.03 & 62.80 & .0050 \\
\hline Residual maximum depth $(\mathrm{m})$ & 91 & .48 & .18 & 30 & .48 & .27 & .8872 \\
\hline Residual pool volume $\left(\mathrm{m}^{3}\right)$ & 91 & 44.17 & 30.48 & 30 & 42.27 & 37.03 & .7752 \\
\hline Pool tail depth $(\mathrm{m})$ & 106 & .25 & .12 & 53 & .37 & .10 & 1.0000 \\
\hline Width/depth ratio & 106 & 21.87 & 8.16 & 53 & 19.05 & 5.86 & .0137 \\
\hline Single LWD/100 m & 103 & 5.26 & 8.57 & 53 & 9.58 & 13.09 & .0312 \\
\hline Aggregate LWD/100 m & 103 & 2.55 & 5.43 & 53 & 1.88 & 4.22 & .3914 \\
\hline Rootwad LWD/100 m & 103 & .52 & 1.98 & 53 & .30 & 1.68 & ${ }^{1} .4767$ \\
\hline Percent fines & 102 & 15.99 & 11.56 & 52 & 11.63 & 7.19 & .0047 \\
\hline Percent gravel & 102 & 25.28 & 12.86 & 52 & 20.42 & 6.58 & .0023 \\
\hline Percent rubble & 102 & 24.98 & 9.80 & 52 & 19.56 & 5.60 & .0001 \\
\hline Percent cobble & 102 & 16.27 & 8.25 & 52 & 19.56 & 5.57 & .0040 \\
\hline Percent boulder & 102 & 15.19 & 10.05 & 52 & 24.65 & 8.76 & ${ }^{1} .0000$ \\
\hline
\end{tabular}

1 -test for equal variances used.

Table 7-Pool frequencies by study area at overall, "B" channels only, and equal drainage area levels of resolution

\begin{tabular}{|c|c|c|c|c|c|c|c|c|}
\hline & \multicolumn{4}{|c|}{ Boulder Creek } & \multicolumn{4}{|c|}{ Rapid River } \\
\hline & \multicolumn{2}{|c|}{ Deep } & \multicolumn{2}{|c|}{ Shallow } & \multicolumn{2}{|c|}{ Deep } & \multicolumn{2}{|c|}{ Shallow } \\
\hline & No./100 m & $\begin{array}{l}\text { Percent } \\
\text { length }\end{array}$ & No./100 m & $\begin{array}{l}\text { Percent } \\
\text { length }\end{array}$ & No./100 m & $\begin{array}{l}\text { Percent } \\
\text { length }\end{array}$ & No./100 m & $\begin{array}{c}\text { Percent } \\
\text { length }\end{array}$ \\
\hline Overall & 1.5 & 23.83 & 5.6 & 76.17 & 3.2 & 50.95 & 3.2 & 49.05 \\
\hline " $B$ " channel & .8 & 16.59 & 4.9 & 83.41 & 3.3 & 49.94 & 3.3 & 50.06 \\
\hline "B" channel/equal & .8 & 16.59 & 4.9 & 83.41 & 2.4 & 34.00 & 4.5 & 66.00 \\
\hline
\end{tabular}

\section{Sampling Frequency Analysis}

For selected variables measured in all habitat types, no apparent differences in statistical information provided by habitat attribute statistics for the selected indicator variables were seen at sampling frequencies of 10 percent or greater. There seemed to be some differences in sensitivity to sampling frequency among these variables. Fine sediment statistics, for example, seemed to start fluctuating at about the 20 percent sampling frequency. This 10 percent sampling frequency corresponded to sample sizes of 23 in Rapid River and 37 on Boulder Creek, for a combined sample size of 60 . For habitat-specific variables (pocket pool depth and pool volume), however, sample sizes were small at this frequency, dropping to 10 or less for pool volume. At the 10 percent frequency for these variables, means, standard deviations, and probabilities related to comparisons between means appeared to become unstable. At the 10 percent sampling frequency, estimates of population means generally differed by less than 10 percent from the 100 percent frequency estimate (table 8).

The ability to detect significant differences among means varied with sampling frequency. Nevertheless, except for pool volume, differences detected between means at 100 percent sampling frequency remained also statistically detectable at 10 percent.

Except for pool volume and LWD, data for Rapid River appeared to be less affected by sampling frequency reduction than Boulder Creek data. This may be due to less inherent variability, as is suggested by the generally lower sample standard deviations on Rapid River for any given attribute. The deviations exhibited by pool volume and LWD reflect reduction in channel structure and, therefore, pool diversity. 
Table 8-Comparisons of means, standard deviations of potential indicator variables for different sampling frequencies

\begin{tabular}{|c|c|c|c|c|c|c|c|c|}
\hline \multirow[b]{2}{*}{ Variable } & \multicolumn{3}{|c|}{ Boulder Creek } & \multicolumn{3}{|c|}{ Rapid River } & \multirow[b]{2}{*}{ SD } & \multirow[b]{2}{*}{ Prob $>t$} \\
\hline & Frequency & $N$ & Mean & $\overline{\text { SD1 }^{1}}$ & $N$ & Mean & & \\
\hline Maximum depth (m) & $\begin{array}{r}100 \\
67 \\
50 \\
33 \\
25 \\
20 \\
10\end{array}$ & \begin{tabular}{r|}
392 \\
264 \\
198 \\
128 \\
97 \\
78 \\
37
\end{tabular} & $\begin{array}{r}0.59 \\
.59 \\
.60 \\
.60 \\
.59 \\
.58 \\
.56\end{array}$ & $\begin{array}{r}0.25 \\
.24 \\
.25 \\
.27 \\
.30 \\
.24 \\
.20\end{array}$ & $\begin{array}{r}250 \\
168 \\
126 \\
82 \\
61 \\
47 \\
23\end{array}$ & $\begin{array}{l}0.80 \\
.81 \\
.80 \\
.77 \\
.81 \\
.83 \\
.81\end{array}$ & $\begin{array}{r}0.25 \\
.25 \\
.25 \\
.24 \\
.23 \\
.27 \\
.26\end{array}$ & $\begin{array}{r}20.0000 \\
2.0000 \\
2.0000 \\
2.0000 \\
2.0000 \\
2.0000 \\
.0001\end{array}$ \\
\hline Fine substrate (percent) & $\begin{array}{r}100 \\
67 \\
50 \\
33 \\
25 \\
20 \\
10\end{array}$ & $\begin{array}{r}389 \\
260 \\
196 \\
129 \\
97 \\
77 \\
36\end{array}$ & $\begin{array}{l}12.23 \\
12.31 \\
11.36 \\
12.07 \\
12.65 \\
13.29 \\
15.06\end{array}$ & $\begin{array}{r}8.83 \\
9.43 \\
6.35 \\
7.51 \\
9.43 \\
8.69 \\
11.19\end{array}$ & $\begin{array}{r}250 \\
169 \\
125 \\
81 \\
61 \\
48 \\
23\end{array}$ & $\begin{array}{l}8.21 \\
8.38 \\
8.74 \\
7.85 \\
7.92 \\
9.73 \\
7.91\end{array}$ & $\begin{array}{l}5.27 \\
4.89 \\
5.75 \\
6.01 \\
4.27 \\
7.29 \\
6.48\end{array}$ & $\begin{array}{r}.0001 \\
.0001 \\
2.0002 \\
.0001 \\
.0001 \\
2.0197 \\
.0030\end{array}$ \\
\hline $\begin{array}{l}\text { Pocket pool frequency } \\
(\text { No. } / 100 \mathrm{~m})\end{array}$ & $\begin{array}{r}100 \\
67 \\
50 \\
33 \\
25 \\
20 \\
10\end{array}$ & \begin{tabular}{r|}
394 \\
265 \\
199 \\
129 \\
97 \\
78 \\
37
\end{tabular} & $\begin{array}{l}5.01 \\
5.17 \\
5.17 \\
4.68 \\
4.85 \\
4.89 \\
5.07\end{array}$ & $\begin{array}{l}5.86 \\
5.83 \\
6.11 \\
5.93 \\
5.25 \\
5.30 \\
5.44\end{array}$ & $\begin{array}{r}252 \\
170 \\
127 \\
82 \\
61 \\
48 \\
23\end{array}$ & $\begin{array}{r}10.71 \\
10.67 \\
10.15 \\
10.81 \\
11.56 \\
8.79 \\
9.62\end{array}$ & $\begin{array}{l}7.20 \\
7.40 \\
7.99 \\
6.83 \\
6.45 \\
8.00 \\
9.19\end{array}$ & $\begin{array}{l}.0001 \\
.0001 \\
.0001 \\
2.0000 \\
2.0000 \\
.0037 \\
.0392\end{array}$ \\
\hline Pocket pool depth $(m)$ & $\begin{array}{r}100 \\
67 \\
50 \\
33 \\
25 \\
20 \\
10\end{array}$ & $\begin{array}{r}228 \\
160 \\
116 \\
68 \\
60 \\
48 \\
23\end{array}$ & $\begin{array}{l}.37 \\
.36 \\
.37 \\
.37 \\
.35 \\
.34 \\
.34\end{array}$ & $\begin{array}{l}.15 \\
.15 \\
.16 \\
.15 \\
.13 \\
.14 \\
.13\end{array}$ & $\begin{array}{r}213 \\
144 \\
100 \\
69 \\
54 \\
35 \\
19\end{array}$ & $\begin{array}{l}.47 \\
.48 \\
.48 \\
.47 \\
.46 \\
.46 \\
.46\end{array}$ & $\begin{array}{l}.13 \\
.13 \\
.14 \\
.13 \\
.12 \\
.13 \\
.13\end{array}$ & $\begin{array}{l}2.0000 \\
2.0000 \\
2.0000 \\
2.0001 \\
2.0000 \\
2.0003 \\
2.0034\end{array}$ \\
\hline Pool volume $\left(\mathrm{m}^{3}\right)$ & $\begin{array}{r}100 \\
67 \\
50 \\
33 \\
25 \\
20 \\
10\end{array}$ & $\begin{array}{r}106 \\
71 \\
53 \\
35 \\
26 \\
21 \\
10\end{array}$ & $\begin{array}{r}35.59 \\
37.05 \\
3.89 \\
32.62 \\
46.74 \\
42.24 \\
59.89\end{array}$ & $\begin{array}{r}40.52 \\
47.19 \\
24.07 \\
21.75 \\
70.94 \\
80.04 \\
112.28\end{array}$ & $\begin{array}{r}77 \\
52 \\
38 \\
25 \\
20 \\
15 \\
8\end{array}$ & $\begin{array}{r}82.94 \\
71.42 \\
85.00 \\
106.90 \\
67.94 \\
82.83 \\
100.49\end{array}$ & $\begin{array}{r}75.70 \\
62.22 \\
85.15 \\
95.04 \\
63.94 \\
8.59 \\
95.37\end{array}$ & $\begin{array}{r}.0001 \\
.0012 \\
.0005 \\
.0007 \\
2.3003 \\
2.1439 \\
2.4279\end{array}$ \\
\hline $\begin{array}{l}\text { Single LWD frequency } \\
(\text { No./100 m) }\end{array}$ & $\begin{array}{r}100 \\
67 \\
50 \\
33 \\
25 \\
20 \\
10\end{array}$ & $\begin{array}{r}394 \\
265 \\
199 \\
129 \\
97 \\
78 \\
37\end{array}$ & $\begin{array}{l}3.53 \\
3.54 \\
3.93 \\
3.50 \\
3.06 \\
2.72 \\
2.07\end{array}$ & $\begin{array}{l}6.05 \\
5.87 \\
6.97 \\
6.41 \\
5.56 \\
4.88 \\
2.99\end{array}$ & $\begin{array}{r}252 \\
170 \\
127 \\
82 \\
61 \\
48 \\
23\end{array}$ & $\begin{array}{l}5.98 \\
6.36 \\
6.00 \\
5.19 \\
7.07 \\
8.67 \\
7.57\end{array}$ & $\begin{array}{r}8.39 \\
8.82 \\
8.62 \\
7.43 \\
9.63 \\
11.49 \\
9.47\end{array}$ & $\begin{array}{r}.0001 \\
.0003 \\
.0243 \\
2.0795 \\
.0040 \\
.0012 \\
.0121\end{array}$ \\
\hline
\end{tabular}

'SD = sample standard deviation.

2Probability from $t$-test for equal variances.

In addition to evaluating the sampling frequencies that supply approximately equal information about the habitat conditions on a given stream, we can also ask what sample size would be required to allow us to detect a change of a given magnitude in a particular habitat variable. We may be able to detect statistically significant differences in a particular attribute between two streams, but the magnitude of difference may not be biologically important. We address this issue with the power curve analysis of Parkinson and others (1988).

Habitat type attributes that seemed most indicative of differences between Boulder Creek and Rapid River (indicator variables) included maximum 
depth, pocket pool frequency and depth, LWD frequency, pool tail depth, and pool volume. Based on the standard deviations of these variables within " $\mathrm{B}$ " channels, sample sizes required to detect a given level of change for various levels of significance (alpha) and power (1-beta) are plotted in figures 6 through 11.

The variables vary with respect to their ability to detect change, but large changes should be detectable at moderate sample sizes (except for single

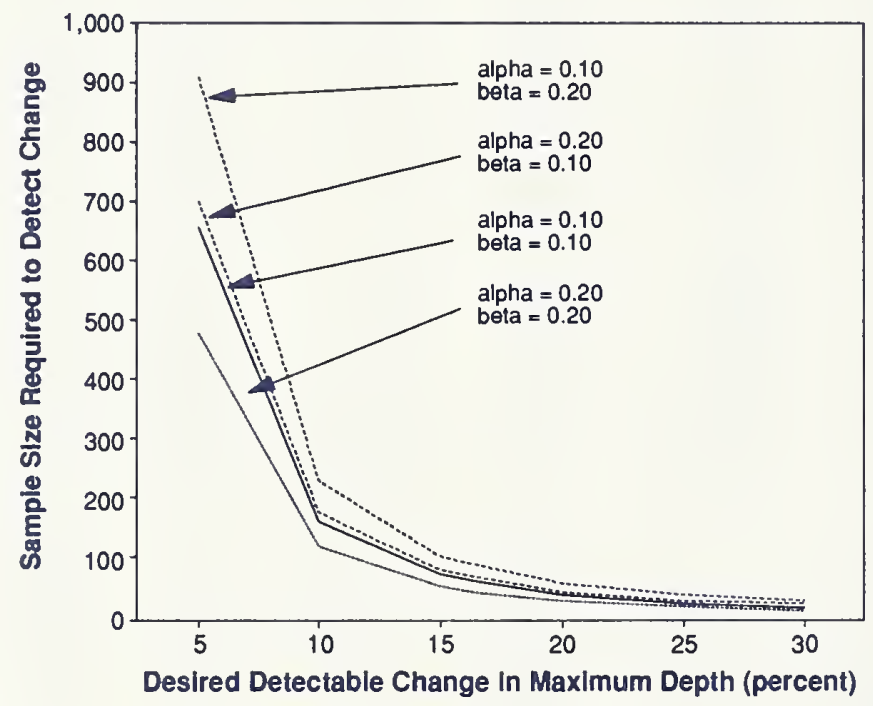

Figure 6-Required sample size as a function of desired detectable change for maximum depth at various levels of significance (alpha) and power (1-beta).

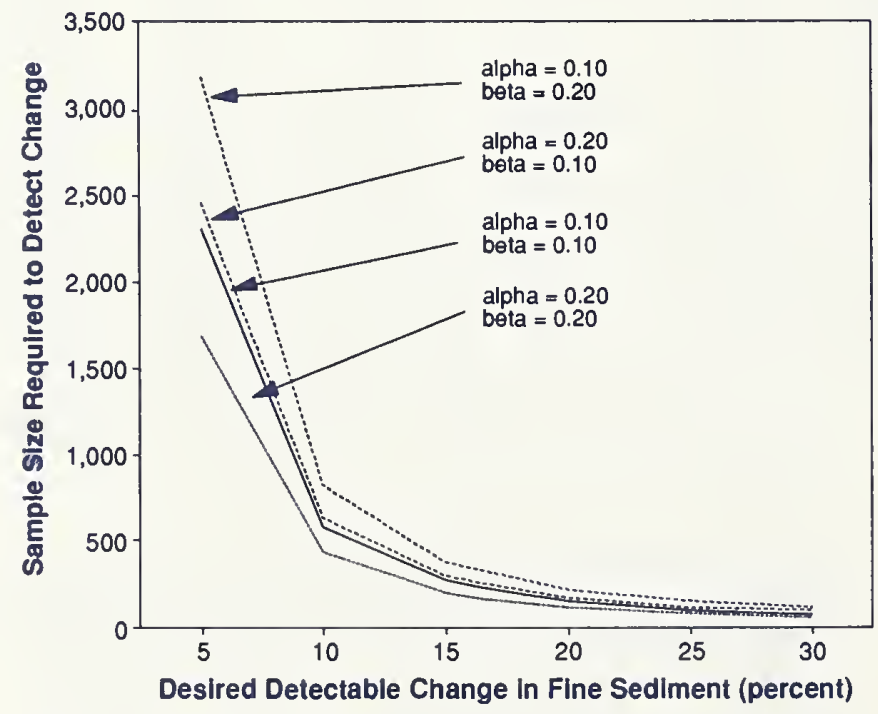

Figure 7-Required sample size as a function of desired detectable change for fine substrate at various levels of significance (alpha) and power (1-beta).
LWD frequency and possibly pool volume), For example, we observed a difference in maximum depth of 36 percent between Boulder Creek and Rapid River "B" channels. Monitoring Boulder Creek to detect an increase in maximum depth of this magnitude at any level of significance or power should be possible with a sample size of about 20 habitat types. On the other hand, the difference in single LWD frequency was 41 percent, but the high variation in the watersheds suggests that nearly 500

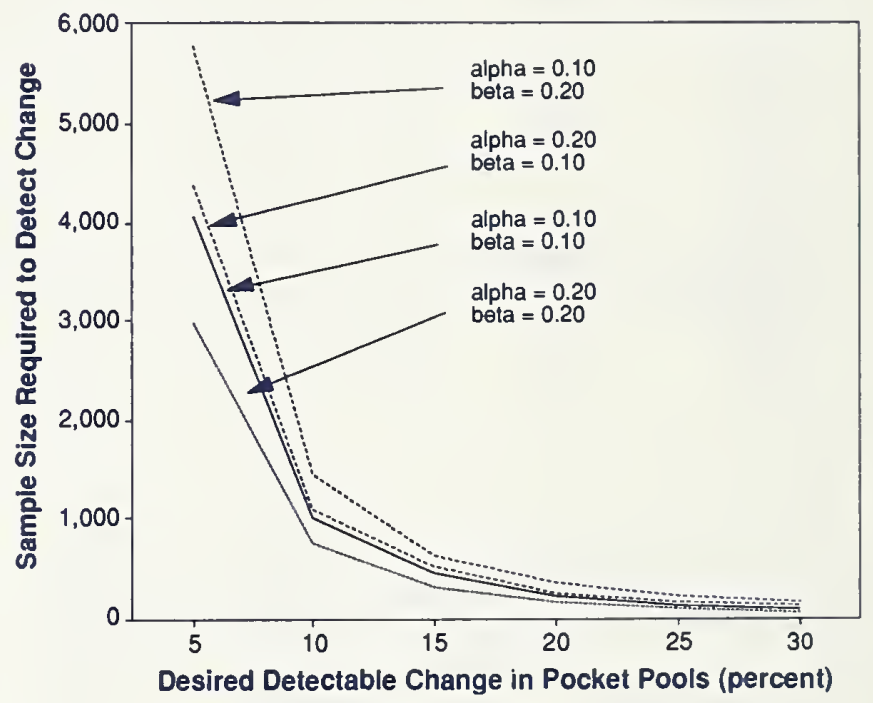

Figure 8-Required sample size as a function of desired detectable change for pocket pool frequency at various levels of significance (alpha) and power (1-beta).

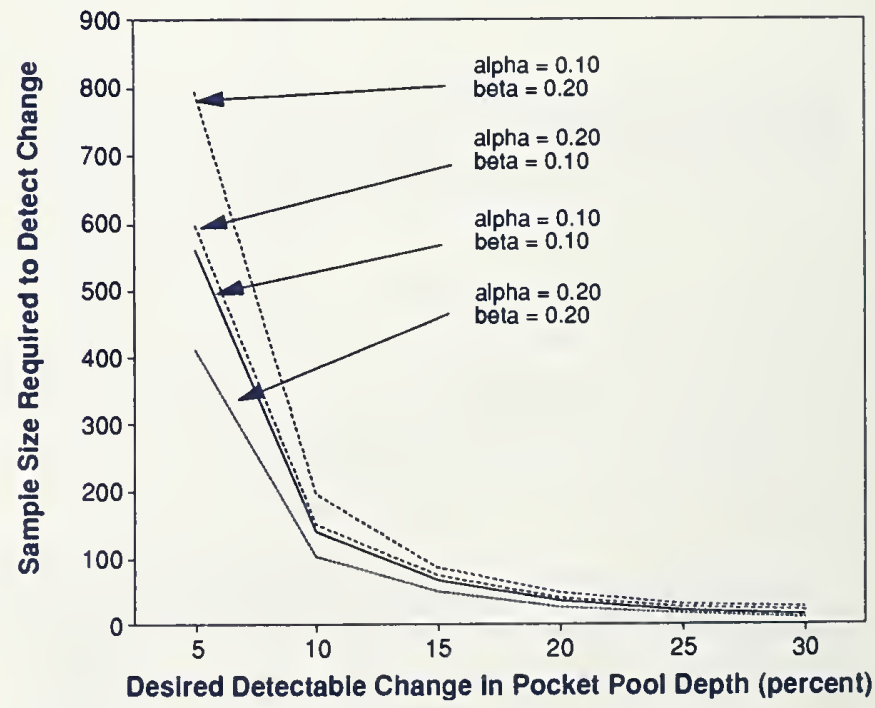

Figure 9-Required sample size as a function of desired detectable change for pocket pool depth at various levels of significance (alpha) and power (1-beta). 


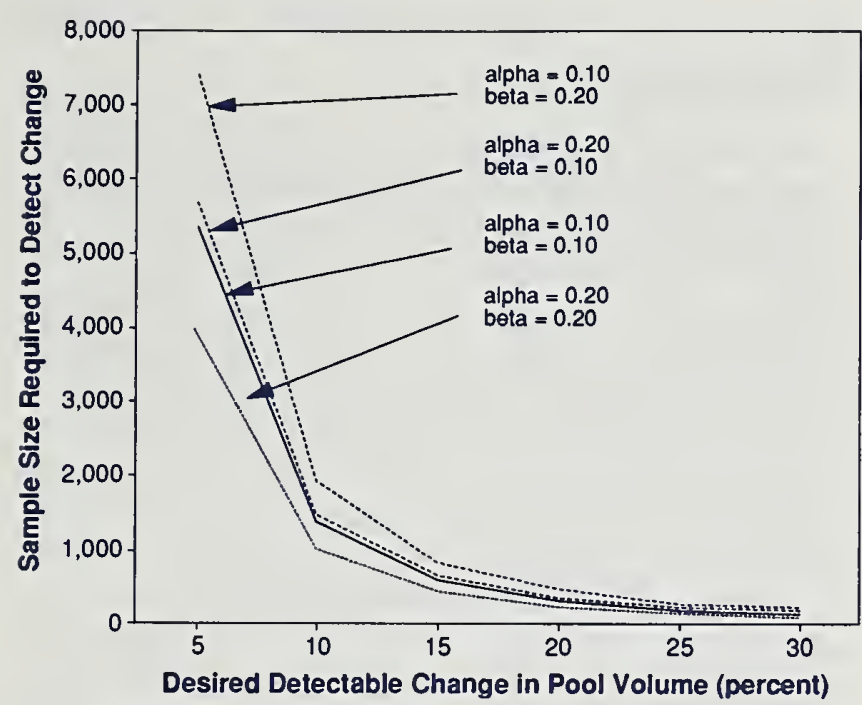

Figure 10-Required sample size as a function of desired detectable change for pool volume at various levels of significance (alpha) and power (1-beta).

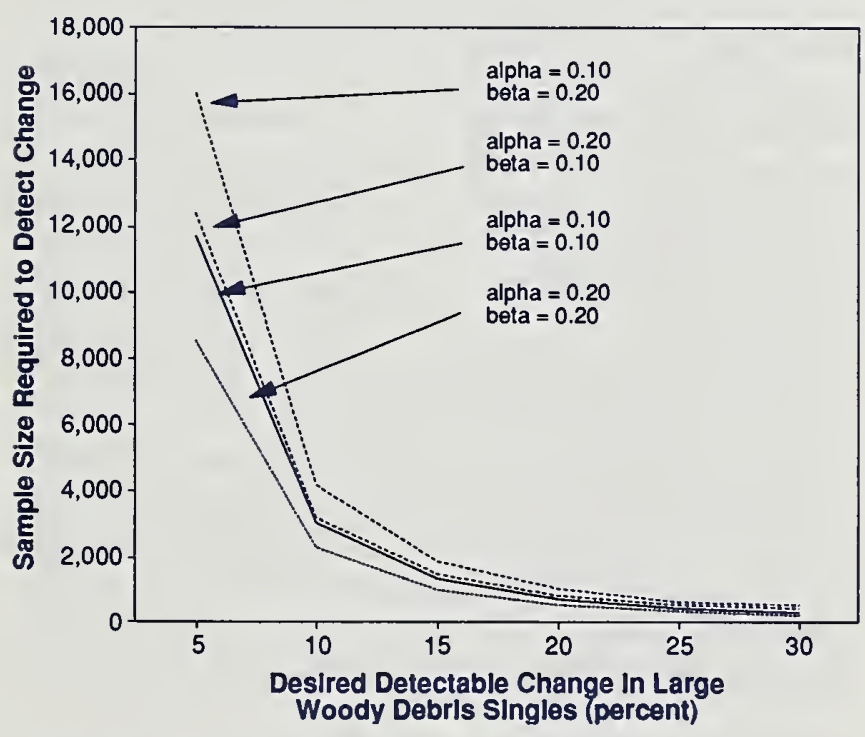

Figure 11-Required sample size as a function of desired detectable change for single large woody debris at various levels of significance (alpha) and power (1-beta).

habitat types would have to be sampled to detect this magnitude of change. The effect on sample size of significance and power levels becomes increasingly important as the desired level of detectable change decreases, sharply increasing sample size requirements.

\section{DISCUSSION}

The first objective of this paper was to determine which of several variables sampled provided a basis for detecting differences in habitat between Boulder Creek and Rapid River. Stream size, gradient, and discharge (tables 3 and 4) influence habitat type dimensions and substrate composition. By reducing the data set to like channel types and drainage areas, we reduced the influence of stream size and gradient so that meaningful comparisons can be made to help detect differences. Unfortunately, however, the Yantis Ditch diverts water so that flows are below the level that would be expected on the basis of catchment area.

In western Washington, Ralph (1992) found the size class of woody debris in intensively logged basins to be appreciably smaller, but the overall number of pieces were not significantly different when comparing intensively logged basins to unharvested basins. The LWD was usually smaller and less stable in clearcut logged stream reaches than in old-growth or buffered areas (Bryant 1983; Toews and Moore 1982). The effects of logging on LWD in the streamside areas results in the decrease in LWD frequency and size over time, as wood is decomposing and moving downstream (Bisson and others 1987; Swanson and Lienkaemper 1978). In-channel LWD size can also be reduced as small pieces of wood are contributed by the smaller second-growth timber (Sedell and others 1988). Boulder Creek and Rapid River have similar streamside vegetation. Streamside logging, road construction, and blowdown removal has occurred along Boulder Creek (USDA FS 1991). The number of single pieces of LWD within Boulder Creek " $\mathrm{B}$ " channel types with like drainage areas is only half of what it is in Rapid River (table 6). The larger diameter ( $>0.6 \mathrm{~m}$ ) LWD in Boulder Creek is shorter than that of Rapid River (fig. 5). Published results showing decreases of LWD frequency and size are consistent with our finding in the logged basin.

Surface fines, stream temperature, LWD, pool frequency and size, and width-to-depth ratios are variables that we expect to respond to changes in sediment delivery, water yield, and LWD availability. In addition to the reduction of summer flows by irrigation withdrawal, logging and roading in Boulder Creek also resulted in sediment yields exceeding natural rates (BOISED model, USDA FS 1992). Boulder Creek has more in-channel fines than Rapid River (12.23 percent versus 9.66 percent, $p<0.01$, table 5). Although this difference was highly significant, the difference between means 
was only 2.57 percent. Megahan (1982) suggests that decreased LWD can result in decreased sediment storage and increased sediment yield at the mouth of a basin. Boulder Creek, with half the LWD of Rapid River, has reduced in-channel storage capacity for sediment, so sediment transport to downstream areas probably is occurring.

Rapid River had significantly larger (area and volume) and deeper (mean and max) pools with a lower width-to-depth ratio, less surface fines, and almost twice the number of single LWD pieces for like " $B$ " channel types and drainage areas (table 6). Pool widths were not significantly different between the streams. In Boulder Creek (table 7), "B" channel types with equal drainage area have fewer pools $(5.7$ versus $6.9 / 100 \mathrm{~m}$ ) than are found in Rapid River. Of those Boulder Creek pools, 86 percent are less than $1 \mathrm{~m}$ deep, compared to Rapid River with 65 percent of pools less than $1 \mathrm{~m}$ deep. Boulder Creek shallow pools have greater length (83.41 versus $66 \mathrm{~m}$ ), where Rapid River deep pools have twice the length (34 versus $16.6 \mathrm{~m}$ ). Rapid River has twice as many pocket pools ( 11.12 versus $5.00 / 100 \mathrm{~m}$ ) that are significantly deeper $(0.46$ versus $0.37 \mathrm{~m}$, $p=0.001$ ) than those of Boulder Creek (table 5). These differences may be a result of the Boulder Creek channel adjusting to increases in sediment, water yield, and decreases in LWD resulting from timber harvest in Boulder Creek. Forest management can alter channel morphology by changing the amount of sediment and water contributed to streams. Excessive sediment can smooth the channel gradient by filling pools and by removal of woody debris, which reduces sediment storage and eliminates the local hydraulic variability (Heede and Rinne 1990; Sullivan and others 1987). Number, area, and volume of pools decreased as a result of the removal of LWD (Bilby 1984). Heifetz and others (1986) observed less large organic debris and less pool area in stream reaches bordering clearcuts. The reduced volume of water due to the Yantis Ditch diversion is another probable cause of observed pool differences, most likely affecting pool depth and volume in the upper reaches of Boulder Creek.

Width-to-depth ratios for " $B$ " channel and like drainage areas were not significantly different, nor were the mean widths or mean depth. But the difference in mean maximum depth was highly significant (table 5), and differences in pool width to depth ratios were highly significant (table 6). The lack of differences in width is probably due to the resistant nature of " $B$ " channels, as banks were stable and well armored, and the mean maximum depth is probably due to the reduced water volume resulting from the Yantis Ditch diversion.

\section{SAMPLING FREQUENCY GUIDELINES}

The second study objective was to determine the sampling frequencies that were required to detect differences between systems so that the most costeffective inventory strategy can be applied. At reduced sampling frequencies, we observed similarity in most habitat variable means and standard deviations and still had the ability to detect significant differences between the two streams. The 10 percent sampling frequency corresponds to sample sizes of at least 20 to 25 habitat types from each stream; 30 percent sampling frequency corresponds to at least 75 to 117 habitat types from each stream. We concluded that assessment of every tenth habitat type represents an adequate inventory for describing $12 \mathrm{~km}$ of stream, or for looking for habitat differences between $12 \mathrm{~km}$ of similar reach types on two streams for most of the variables analyzed. Sampling longer sections should require reduced sampling frequency to maintain samples of an adequate size.

Our analysis of samples needed to detect differences between Boulder Creek and Rapid River suggests that this type of inventory may be less than perfect in monitoring efforts. One of the most obvious differences between the logged Boulder Creek watershed and the nearly pristine Rapid River watershed was the frequency of single pieces of LWD. Unfortunately, to detect a 41 percent increase (the difference we observed) in LWD would require sampling about 500 habitat units. Five hundred units in Rapid River and Boulder Creek is equivalent to our 100 percent sampling frequency.

Based on this study, we would recommend sampling approximately 30 percent of the habitat types or ensuring that 75 to 100 habitat types are sampled for the analyzed variables, except LWD. If LWD is going to be used for assessing habitat condition, we recommend counting $L W D$ in all habitat types.

\section{CONCLUSIONS}

We conclude that the frequency and maximum depth of pools, and the frequency and size of single pieces of LWD were different in Boulder Creek and Rapid River when the same channel types and similar drainage areas were compared. The differences are those that one would predict to be produced by the timber harvest and flow diversion, based on the literature. Our sampling intensity did permit detection of differences in sediment and in the frequency and size of LWD. Differences in pool characteristics were detected at a 10 percent sampling frequency. Because of high inherent variation, detecting differences in LWD requires that all habitat types be sampled. 


\section{REFERENCES}

Beschta, R. L.; Platts, W. S. 1986. Morphological features of small streams: significance and function. Water Resources Bulletin. 22(3): 369-380.

Bilby, R. E. 1984. Removal of woody debris may affect stream channel stability. Journal of Forestry. 82(10): 609-613.

Bisson, P. A.; Nielson, J. L.; Palmason, R. A.; Grove, L. E. 1982. A system of naming habitat types in small streams, with examples of habitat utilization by salmonids during low stream flow. In: Armantrout, N. B., ed. Acquisition and utilization of aquatic habitat inventory information. Bethesda, MD: American Fisheries Society: 62-73, 376.

Bisson, P. A.; Bryant, M. D.; Dolloff, C. A.; Grette, G. B.; House, R. A.; Murphy, M. L.; Koski, K. V.; Sedell, J. R. 1987. Large woody debris in forested streams in the Pacific Northwest: past, present, and future. In: Salo, E. O.; Cundy, T. W., eds. Streamside management: forestry and fishery interactions. Contrib. 57. Seattle, WA: University of Washington, Institute of Forest Resources: 143-190.

Bozek, M. A.; Rahel, F. J. 1991. Assessing habitat requirements of young Colorado River cutthroat trout by use of macrohabitat and microhabitat analysis. Transactions of the American Fisheries Society. 120: 571-581.

Bryant, M. D. 1983. The role and management of woody debris in West Coast salmonid nursery streams. North American Journal of Fisheries Management. 3: 322-330.

Clifton, C. 1989. Effects of vegetation and land use on channel morphology. In: Gresswell, R. E.; Barton, B. A.; Kershner, J. L., eds. Practical approaches to riparian resource management. Billings, MT: U.S. Department of the Interior, Bureau of Land Management: 121-129.

Hankin, D. G.; Reeves, G. H. 1988. Estimating total fish abundance and total habitat area in small streams based on usual estimation methods. Canadian Journal of Fisheries and Aquatic Sciences. 45: 834-844.

Hall, J. D.; Lantz, R. L. 1969. Effects of logging on the habitat of coho salmon and cutthroat trout in coastal streams. In: Northcote, T. G., ed. Symposium on salmon and trout in streams. $H$. R. MacMiller Lectures in Fisheries. Vancouver, BC: University of British Columbia: 355-375.

Heede, B. H.; Rinne, J. N. 1990. Hydrodynamic and fluvial morphologic processes: implications for fisheries management and research. North American Journal of Fisheries Management. 10: 249-268.
Heifetz, J.; Murphy, M. L.; Koski, K. V. 1986. Effects of logging on winter habitat of juvenile salmonids in Alaskan streams. North American Journal of Fisheries Management. 6: 52-58.

Kozel, S.J. 1987. Trends in habitat features and trout abundance among unaltered stream reaches on the Medicine Bow National Forest. Laramie, WY: University of Wyoming. 145 p. Thesis.

Lisle, T. E. 1989. Using "residual depths" to monitor pool depths independently of discharge. Res. Note PSW-394. Berkeley, CA: U.S. Department of Agriculture, Forest Service, Pacific Southwest Forest and Range Experiment Station. 4 p.

Lisle, T. E. 1981. Channel recovery from recent large floods in north coastal California: rates and processes. In: Coats, R. N., ed. Proceedings of a symposium on watershed rehabilitation in Redwood National Park and other pacific coastal areas. Napa, CA: John Muir Institute, Center for Natural Resource Studies: 153-160.

Lisle, T. E. 1982. Effects of aggradation and degradation on riffle-pool morphology in natural gravel channels, northwestern California. Water Resource Research 18(6): 1643-1651.

Lobb, M. D., III; Orth, D. J. 1991. Habitat use by an assemblage of fish in a large warmwater stream. Transactions of the American Fisheries Society. 120: 65-78.

McCain, M. E.; Fuller, D. D.; Decker, L. M.; Overton, C. K. 1990. Stream habitat classification and inventory procedures for northern California. FHR Currents No. 1. USFS R-5 Anadromous Fish Habitat Relationships Tech. Bull. San Francisco, CA: U.S. Department of Agriculture, Forest Service, Pacific Southwest Region. 15 p.

Megahan, W. F. 1982. Channel sediment storage behind obstructions in forested drainage basins draining the granitic bedrock of the Idaho Batholith. In: Swanson, F. J.; Janda, R. J.; Dunne, T.; Swanson, D. N., eds. Sediment budgets and routing in forested drainage basins. Gen. Tech. Rep. PNW-141. Portland, OR: U.S. Department of Agriculture, Forest Service, Pacific Northwest Forest and Range Experiment Station: 114-121.

Megahan, W. F.; Platts, W. S.; Kulesza, B. 1980. Riverbed improves over time: South Fork Salmon. In: Symposium on watershed management. New York: American Society of Civil Engineers. 1: 380-395.

Modde, T.; Ford, R. C.; Parsons, M. G. 1991. Use of a habitat-based stream classification system for categorizing trout biomass. North American Journal of Fisheries Management. 11: 305-311. 
Murphy, M. L.; Heifetz, J.; Johnson, S. W.; Doski, K.V.; Thedinga, J. F. 1986. Effects of clear-cut logging with and without buffer strips on juvenile salmonids in Alaskan streams. Canadian Journal of Fisheries and Aquatic Sciences. 43: 1521-1533.

Parkinson, E. A.; Barkowitz, J.; Bull, C. J. 1988. Sample size requirements for detecting changes in some fisheries statistics from small trout lakes. North American Journal of Fisheries Management. 8: 181-190.

Ralph, S. C. 1992. The impact of logging on instream habitat-a preview of results. Streamside Runoff. 6(3): 1-2.

Robison, E. G.; Beschta, R. L. 1990. Coarse woody debris and channel morphology interactions for undisturbed streams in Southeast Alaska, USA. Earth Surface Processes and Land Forms. 15: 149-156.

Rosgen, D. L. 1985. A stream classification system. In: Johnson, R. R.; Ziebell, C. D.; Palton, D. R.; Ffolliott, P. F.; Hamre, R. H., eds. In: Riparian ecosystems and their management: reconciling conflicting uses: Proceedings, first North American riparian conference; 1985 April 16-18; Tucson, AZ. Gen. Tech. Rep. RM-120. Fort Collins, CO: U.S. Department of Agriculture, Forest Service, Rocky Mountain Forest and Range Experiment Station: 91-95.

Sedell, J. R.; Bisson, P. A.; Swanson, F. J.; Gregory, S. V. 1988. What we know about large trees that fall into streams and rivers. In: Maser, C.; [and others], eds. From the forest to the sea: a story of fallen trees. Gen. Tech. Rep. PNW-GTR-229. Portland, OR: U.S. Department of Agriculture, Forest Service, Pacific Northwest Research Station. 153 p.
Sullivan, K.; Lisle, T. E.; Dolloff, C. A.; Grant, G. E.; Reid, L. M. 1987. Stream channels: the link between forests and fishes. In: Salo, E. O.; Cundy, T. W., eds. Streamside management: forestry and fisheries interactions. Contrib. 57. Seattle, WA: University of Washington, Institute of Forest Resources: 39-97.

Swanson, F. J.; Lienkaemper, G. W. 1978. Physical consequences of large organic debris in Pacific Northwest streams. Gen. Tech. Rep. PNW-69. Portland, OR: U.S. Department of Agriculture, Forest Service, Pacific Northwest Forest and Range Experiment Station. 15 .

Toews, D. A. A.; Moore, M. K. 1982. The effects of three streamside logging treatments on large organic debris and channel morphology of Carnation Creek. In: Hartman, G. F., ed. Proceedings of the Carnation Creek workshop: a ten-year review. Nanaimo, BC: Pacific Biological Station: 129-153.

U.S. Department of Agriculture, Forest Service. 1991. Draft Boulder Bottom proposal - affected environment and environmental consequences. Unpublished report. McCall, ID: U.S. Department of Agriculture, Forest Service, Intermountain Region, Payette National Forest.

U.S. Department of Agriculture, Forest Service. 1992. Lockwood and North Round Valley timber sales: draft environmental impact statement. Ogden, UT: U.S. Department of Agriculture, Forest Service, Intermountain Region.

U.S. Department of Agriculture, Forest Service. [Undated]. Draft report on file. McCall, ID: Payette National Forest.

Wolman, M. G. 1954. A method of sampling coarse riverbed material. Transactions of the American Geophysical Union. 35(6): 951-956. 



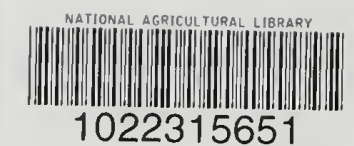

Overton, C. Kerry; Radko, Michael A.; Nelson, Rodger L. 1993. Fish habitat conditions: using the Northern/Intermountain Regions' inventory procedures for detecting differences on two differently managed watersheds. Gen. Tech. Rep. INT-300. Ogden, UT: U.S. Department of Agriculture, Forest Service, Intermountain Research Station. 14 p.

Differences in fish habitat variables between two studied watersheds may be related to differences in land management. In using the R1/R4 Watershed-Scale Fish Habitat Inventory Process, for most habitat variables, evaluations of sample sizes of at least 30 habitat units were adequate. Guidelines will help land managers in determining sample sizes required to detect differences, under varying management, of such variables as channel morphology, substrate, large woody debris, and bank conditions.

KEYWORDS: habitat variables, sampling frequency, logging effects, channel morphology, streams 


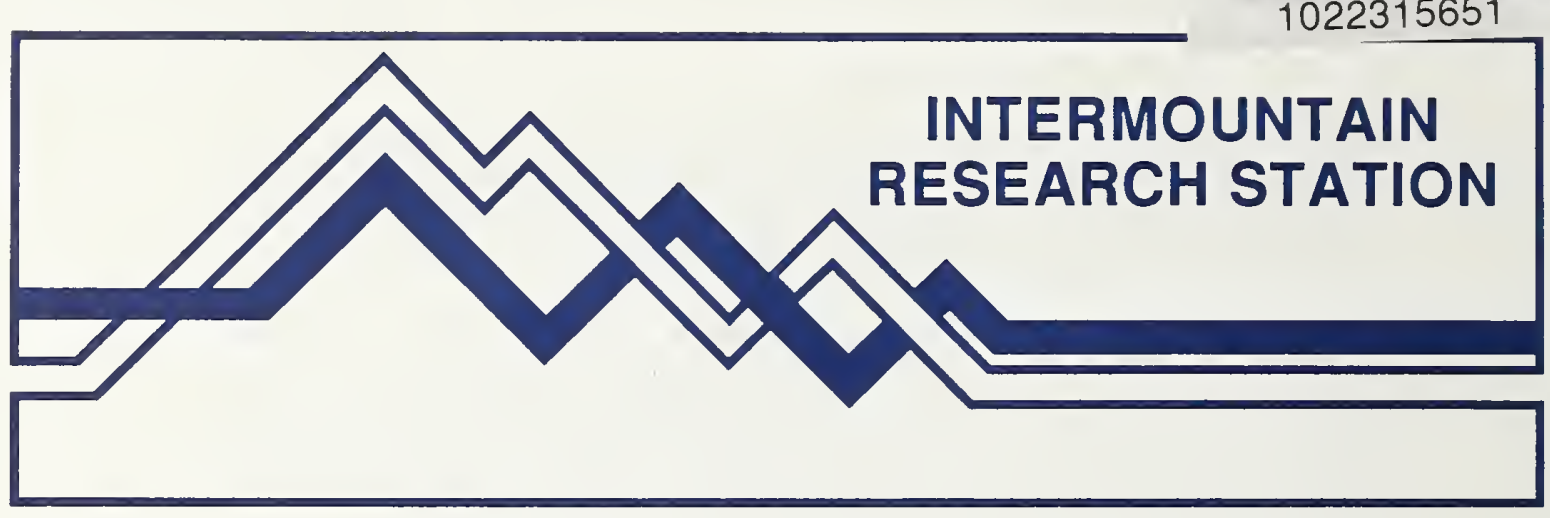

The Intermountain Research Station provides scientific knowledge and technology to improve management, protection, and use of the forests and rangelands of the Intermountain West. Research is designed to meet the needs of National Forest managers, Federal and State agencies, industry, academic institutions, public and private organizations, and individuals. Results of research are made available through publications, symposia, workshops, training sessions, and personal contacts.

The Intermountain Research Station territory includes Montana, Idaho, Utah, Nevada, and western Wyoming. Eighty-five percent of the lands in the Station area, about 231 million acres, are classified as forest or rangeland. They include grasslands, deserts, shrublands, alpine areas, and forests. They provide fiber for forest industries, minerals and fossil fuels for energy and industrial development, water for domestic and industrial consumption, forage for livestock and wildlife, and recreation opportunities for millions of visitors.

Several Station units conduct research in additional western States, or have missions that are national or international in scope.

Station laboratories are located in:

Boise, Idaho

Bozeman, Montana (in cooperation with Montana State University)

Logan, Utah (in cooperation with Utah State University)

Missoula, Montana (in cooperation with the University of Montana)

Moscow, Idaho (in cooperation with the University of Idaho)

Ogden, Utah

Provo, Utah (in cooperation with Brigham Young University)

Reno, Nevada (in cooperation with the University of Nevada)

The policy of the United States Department of Agriculture Forest Service prohibits discrimination on the basis of race, color, national origin, age, religion, sex, or disability, familial status, or political affiliation. Persons believing they have been discriminated against in any Forest Service related activity should write to: Chief, Forest Service, USDA, P.O. Box 96090, Washington, DC 20090-6090. 